\title{
Maternal satisfaction with delivery services at tertiary university hospital in upper Egypt, is it actually satisfying?
}

\author{
Waleed Sayed ${ }^{1}$, Diaa Eldeen M. Abd ElAal' ${ }^{2}$ Hazem S. Mohammed ${ }^{2}$, \\ Ahmed M. Abbas' ${ }^{2}$, Kamal M. Zahran ${ }^{2 *}$
}

\begin{abstract}
${ }^{1}$ Department of Obstetrics and Gynecology, Manflout Reproductive Health Hospital, Assiut, Egypt
${ }^{2}$ Department of Obstetrics and Gynecology, Woman's Health Hospital, Faculty of Medicine, Assiut University, Egypt
\end{abstract}

Received: 12 May 2018

Accepted: 05 June 2018

*Correspondence:

Dr. Kamal M. Zahran,

E-mail: drzahranmk@gmail.com

Copyright: () the author(s), publisher and licensee Medip Academy. This is an open-access article distributed under the terms of the Creative Commons Attribution Non-Commercial License, which permits unrestricted non-commercial use, distribution, and reproduction in any medium, provided the original work is properly cited.

\begin{abstract}
Background: Maternal health has therefore become an important aspect of policy and planning for healthcare, as reflected by its inclusion as the fifth Millennium Development Goal (MDG). The objective of the present investigation was to determine the maternal satisfaction towards delivery services at Women's Health Hospital, Assiut University, Upper Egypt

Methods: A cross sectional study was performed. The study was conducted during February- April 2016 on a sample of 400 delivering mothers; the data were collected using a semi-structured questionnaire and analyzed by SPSS version21. Statistical tests were used, and significance level was taken at p-value $<0.05$.

Results: A total of 400 delivering mothers were interviewed, of which $67.0 \%$ of the respondents were between the age group of $20-30,76.75 \%$ were from rural areas, $48.0 \%$ were illiterate, $86.75 \%$ were house wives and $46.0 \%$ belonged to the income group of less than 500 EGP. The findings of the study showed that the overall maternal satisfaction level with the delivery services rendered at the hospital was $78.5 \%$, while $21.5 \%$ were dissatisfied. Furthermore, satisfaction with the delivery service was found to have a significant association with the age of the respondents and educational level of the respondents. Moreover, results suggest that women are satisfied with the communication factors, interpersonal behavior, good management, and general satisfaction. Women were least satisfied with privacy sensation during hospital stay and obligatory blood donation.

Conclusions: Although most participants were satisfied by the delivery service provided to them during delivery, Dissatisfaction by a minority group resulted in a limited ability of communication with mothers, lack of privacy sensation during hospital stay and obligatory blood donation. Thus, mechanisms should be developed to increase maternal satisfaction in our hospital.
\end{abstract}

Keywords: Delivery, Maternal, Pregnancy, Satisfaction

\section{INTRODUCTION}

Satisfaction is an individual's state of being pleased with an event. Lari and colleagues defined patient satisfaction as the extent of an individual's experience compared with her expectations. Or: What patients' and the population as a whole desire to receive from health care services. ${ }^{1}$
Satisfied patients are likely to return to the services they need and to recommend the services to others. Patients are considered the best people to know what is best for them and their communities. ${ }^{2}$ Patients are naturally more satisfied when they are empowered with knowledge. ${ }^{3}$ Another important finding was that, patients want to be informed, have choices and be protected; hence, 
providers should strive to provide an environment, which both empowers and protects patients. ${ }^{4}$

Maternal health has therefore become an important aspect of policy and planning for healthcare, as reflected by its inclusion as the fifth Millennium Development Goal (MDG). ${ }^{5}$

WHO encourages the presence of skilled doctors at each birth to reduce maternal mortality and recommends that women's satisfaction be assessed to improve the quality and effectiveness of health care. ${ }^{5}$ For that: Maternal health researchers Affirms the importance of assessing women's evaluations of their birth experiences in order to identify the medical and psychosocial factors that contribute to poor outcomes. ${ }^{6}$

Maternal satisfaction with the delivery service may have immediate and remote effects on health of the mothers. Negative feedback of childbirth process, immediately: increases the risk of post-partum depression and dissatisfaction and remotely: change the maternal attitudes towards future pregnancies and future choice of mode of delivery. However, some identified negative impacts were reflected in a number of health outcomes, including maternal and infant mortality rate, perinatal infections, perceived health status, and hygiene compliance. Feelings of satisfaction are essential to maintaining maternal health, as well as providing continuous quality care of maternal and child health. ${ }^{7}$ In short, continuity of maternal and child care is related to the levels of satisfaction of mother and family members with health providers and health facilities. ${ }^{8}$

Patient satisfaction is a key determinant of quality of care and an important component in measuring performance. ${ }^{9}$ In addition, it is important that the hospitals promoting client-oriented health services should carry out in-depth research on factors determining satisfaction in the respective culture. ${ }^{10}$

Therefore, the specific objective of the study was to determine or to assess maternal satisfaction with the care they received when they came to deliver at women's health hospital, Assiut University. Hopefully, the results of this study will provide scientific evidence regarding maternal satisfaction with delivery care. Consideration of satisfaction by health policy makers might be necessary for improving the quality of mother care and reducing maternal mortality rate.

\section{METHODS}

This cross-section hospital-based study was conducted at Women's Health Hospital, Assiut University, in the period between February to April 2016. Delivered mothers who were at postpartum wards were invited to participate in the study. Women who delivered outside the hospital were excluded.

\section{Sample Size calculation}

The sample size was determined using Epi- Info. Program with confidence level $(95 \%)$ and confidence interval $(5 \%)$. The sample size estimated to be (384) postpartum mothers. Hence, we interviewed a total of 400 women.

\section{Outcomes of the study}

The primary outcome was to determine maternal satisfaction with delivery services. Secondary outcomes included other factors that may affect the maternal satisfaction as socio-demographic characteristics including age, marital status, education, occupation, level of family monthly income, parity, mode of labor for last delivery and maternal and neonatal outcome.

\section{Data Collection tool and method}

The data were collected by interviewing the mothers after delivery using a semi-structured questionnaire which has three parts.

The first part asks about socio-demographic information of mothers, the second part asked about health worker attitude and communications. Finally, the satisfaction of mothers was measured using 17 questions which were adopted from Donabedian quality assessment framework. ${ }^{11}$

\section{Statistical analysis}

Data were entered and analyzed by using SPSS "version 21 ". Statistical tests were used, and significance level was taken at $\mathrm{p}$-value $<0.05$.

\section{RESULTS}

The study included 400 mothers; the majority $67.0 \%$ belonged to the age group 20-30 years, $76.75 \%$ were from rural areas, $48.0 \%$ were illiterate, $86.75 \%$ were house wives and $46.0 \%$ belonged to the income group of less than 500 EGP.

The mean age of the mothers was $25.74 \pm 5.02$ (SD) years. More than half $(66.5 \%)$ of women had 1-5 deliveries, while $(33.5 \%)$ of women were their first delivery, $(51 \%)$ of them were delivered by cesarean section while $(49 \%)$ of them were delivered vaginally (Table 1).

Table 2 shows the Health Workers' Attitude related respondent's satisfaction. High percentage of the respondents stated that the medical team welcomed them at admission, the behavior of the medical team was good, and they always got the full attention of the medical team. But the medical team did not identify themselves to the respondents. 
Table 1: Socio-demographic characteristics of the study participants.

\begin{tabular}{|c|c|c|}
\hline Item & Frequency $(\mathrm{N}=400)$ & Percentage \\
\hline \multicolumn{3}{|l|}{ Age (years) } \\
\hline Mean \pm SD & $25.74 \pm 5.02$ & \\
\hline$<20$ years. & 69 & $17.2 \%$ \\
\hline 20-30 years. & 268 & $67.0 \%$ \\
\hline >30years. & 63 & $15.8 \%$ \\
\hline \multicolumn{3}{|l|}{ Residence } \\
\hline Rural & 307 & $76.75 \%$ \\
\hline Urban & 93 & $23.2 \%$ \\
\hline \multicolumn{3}{|l|}{ Education } \\
\hline Illiterate & 192 & $48.0 \%$ \\
\hline Read and Write & 20 & $5.0 \%$ \\
\hline $\begin{array}{l}\text { Primary and } \\
\text { preparatory }\end{array}$ & 99 & $24.8 \%$ \\
\hline University & 89 & $22.2 \%$ \\
\hline \multicolumn{3}{|l|}{ Marital Status } \\
\hline Married & 398 & $99.5 \%$ \\
\hline Widowed & 2 & $0.5 \%$ \\
\hline Divorced & 0 & 0 \\
\hline \multicolumn{3}{|l|}{ Work } \\
\hline Housewife & 347 & $86.75 \%$ \\
\hline Work & 53 & $13.25 \%$ \\
\hline \multicolumn{3}{|l|}{ Income/month } \\
\hline Less than 500 EGP & 184 & $46.0 \%$ \\
\hline $\begin{array}{l}\text { Between 500-1000 } \\
\text { EGP }\end{array}$ & 173 & $43.2 \%$ \\
\hline $\begin{array}{l}\text { More than } 1000 \\
\text { EGP }\end{array}$ & 43 & $10.8 \%$ \\
\hline \multicolumn{3}{|l|}{ Mode of delivery } \\
\hline Vaginal & 196 & $49 \%$ \\
\hline C.S & 204 & $51 \%$ \\
\hline \multicolumn{3}{|l|}{ Parity } \\
\hline Mean \pm SD & $3.21 \pm 1.01$ & $3.66 \pm 1.85$ \\
\hline Primipara & 134 & $33.5 \%$ \\
\hline Multipara & 266 & $66.5 \%$ \\
\hline
\end{tabular}

Table 2: Health Workers' Attitude related respondent's satisfaction.

\begin{tabular}{|c|c|c|}
\hline Item & Frequency $(\mathrm{N}=400)$ & Percentage \\
\hline \multicolumn{3}{|c|}{ Welcoming at admission prior to arrival to the ward } \\
\hline Yes & 313 & $78.25 \%$ \\
\hline No & 87 & $21.75 \%$ \\
\hline \multicolumn{3}{|c|}{ If the medical team identified himself to the patient } \\
\hline Yes & 95 & $23.75 \%$ \\
\hline No & 305 & $76.25 \%$ \\
\hline \multicolumn{3}{|c|}{$\begin{array}{l}\text { Badly handling of the patient "bad medical team } \\
\text { behavior" }\end{array}$} \\
\hline Yes & 85 & $21.25 \%$ \\
\hline No & 315 & $78.75 \%$ \\
\hline \multicolumn{3}{|c|}{$\begin{array}{l}\text { Courtesy, full attention and helpfulness of the } \\
\text { medical team towards patients }\end{array}$} \\
\hline Always & 166 & $41.5 \%$ \\
\hline Usually & 194 & $48.5 \%$ \\
\hline Sometimes & 40 & $10 \%$ \\
\hline Never & 0 & 0 \\
\hline
\end{tabular}

As shown in Table 3, the medical team had explained the plan of treatment to only $(61.25 \%)$ of respondents. High percentage $(73.2 \%)$ of the respondents said that they did not receive any encouragement to ask about the plan of treatment or to ask about discharge time. So, the findings would alert the health care system to design a client friendly approach to enhance communication.

Table 3: Communication skills of the medical team with the study participants.

\begin{tabular}{|c|c|c|}
\hline Item & Frequency $(\mathrm{N}=400)$ & Percentage \\
\hline \multicolumn{3}{|c|}{$\begin{array}{l}\text { Explanation of the treatment plan for delivery to } \\
\text { mothers }\end{array}$} \\
\hline Yes & 245 & $61.25 \%$ \\
\hline No & 155 & $38.75 \%$ \\
\hline \multicolumn{3}{|c|}{ Encouragement to ask about plan of treatment } \\
\hline Yes & 107 & $26.8 \%$ \\
\hline No & 293 & $73.2 \%$ \\
\hline \multicolumn{3}{|c|}{ Encouragement to ask about discharge time } \\
\hline Yes & 45 & $11.25 \%$ \\
\hline No & 355 & $88.75 \%$ \\
\hline \multicolumn{3}{|c|}{ Tell mothers about fasting before operation } \\
\hline Yes & 377 & $94.2 \%$ \\
\hline No & 23 & $5.8 \%$ \\
\hline \multicolumn{3}{|c|}{ Give instruction of care before discharge } \\
\hline Yes & 370 & $92.5 \%$ \\
\hline No & 30 & $7.5 \%$ \\
\hline
\end{tabular}

Facilities available in hospital or Environment were found to be one of the major factors affecting client satisfaction outcomes. Of these dimensions, cleanliness, hand hygiene, bathroom facilities and breadth of patient room are important structural determinant of maternal satisfaction (Table 4). Regarding the general assessment of the childbirth process, $(78.5 \%)$ were satisfied and $(21.5 \%)$ of them were dissatisfied (Table 5). The problems that were faced by the respondents in the hospital, the first one was the problem of mandatory blood donation, which represented $(55.0 \%)$, despite that only $(74.8 \%)$ said that they donated blood while (25.2\%) of them did not and the other significant problem was the sense of privacy, which represented $(42.7 \%)$.

Regarding mothers whose evaluated the delivery in Women's health hospital, Assiut University as (good), $(51.0 \%)$ were illiterate while $(100 \%)$ could read and write, $(46.5 \%)$ had primary and preparatory education and $(49.4 \%)$ had university education with a highly significant difference $(\mathrm{P}=0.0001)$ with type of education. From these findings the satisfaction was found to be inversely proportional to the educational level (Table 6).

Almost half of the mothers $(46 \%)$ who had poor expectation were highly satisfied. In addition, mothers who had good expectation (47\%) also, were highly satisfied. However, there was no significant association between expectation level and maternal satisfaction (Table 7). 
Table 4: Maternal satisfaction related to facilities available in hospital.

\begin{tabular}{|c|c|c|}
\hline Item & Frequency $(\mathrm{N}=400)$ & Percentage \\
\hline \multicolumn{3}{|c|}{ Breadth of the patient's or labour ward room } \\
\hline Excellent & 86 & $21.5 \%$ \\
\hline Very good & 180 & $45.0 \%$ \\
\hline Good & 0 & 0 \\
\hline Suitable & 134 & $33.5 \%$ \\
\hline Poor & 0 & 0 \\
\hline \multicolumn{3}{|c|}{ Quietness in the patient's room } \\
\hline Excellent & 0 & 0 \\
\hline Very good & 166 & $41.5 \%$ \\
\hline Good & 222 & $5.5 \%$ \\
\hline Suitable & 12 & $3 \%$ \\
\hline Poor & 0 & 0 \\
\hline \multicolumn{3}{|c|}{ Cleanliness of the patient's room } \\
\hline Excellent & 0 & 0 \\
\hline Very good & 125 & $31.25 \%$ \\
\hline Good & 232 & $58.0 \%)$ \\
\hline Suitable & 43 & $10.75 \%$ \\
\hline Poor & 0 & 0 \\
\hline \multicolumn{3}{|c|}{ Hand hygiene of the medical team } \\
\hline Excellent & 0 & 0 \\
\hline Very good & 115 & $28.75 \%$ \\
\hline Good & 203 & $50.75 \%$ \\
\hline Suitable & 82 & $20.5 \%$ \\
\hline Poor & 0 & 0 \\
\hline \multicolumn{3}{|c|}{ Bathroom facilities and cleanliness } \\
\hline Excellent & 13 & $3.2 \%$ \\
\hline Very good & 0 & 0 \\
\hline Good & 228 & $57.0 \%$ \\
\hline Suitable & 159 & $39.8 \%$ \\
\hline Poor & 0 & 0 \\
\hline \multicolumn{3}{|c|}{ Quality of food } \\
\hline No food & 28 & $7.0 \%$ \\
\hline Excellent & 0 & 0 \\
\hline Very good & 26 & $6.5 \%$ \\
\hline Good & 153 & $38.25 \%$ \\
\hline Suitable & 193 & $48.25 \%$ \\
\hline Poor & 0 & 0 \\
\hline
\end{tabular}

Table 5: General assessment of the childbirth process.

\begin{tabular}{|c|c|c|}
\hline Item & Frequency $(\mathrm{N}=400)$ & Percentage \\
\hline \multicolumn{3}{|c|}{ Satisfaction with the admission Process } \\
\hline Yes & 294 & $(73.5 \%)$ \\
\hline No & 106 & $(26.5 \%)$ \\
\hline \multicolumn{3}{|c|}{ General assessment of the child birth process } \\
\hline Excellent & 0 & 0 \\
\hline Very good & 92 & $(23 \%)$ \\
\hline Good & 222 & $(55.5 \%)$ \\
\hline Suitable & 65 & $(16.25 \%)$ \\
\hline Poor & 21 & $(5.25 \%)$ \\
\hline
\end{tabular}

\section{DISCUSSION}

From this study it was found that there was an association between age group and education with overall satisfaction being statically significant. Where it was found the satisfaction increased with increased age and lower educational status. Also, the findings of our study would alert the policy makers to design a patient friendly approach to enhance the health workers behavior and communication.

This aspect appeared to be much more important to patients than technical ability of providers. Regarding participants' educational status, less educated mothers have higher satisfaction than the educated ones. $48 \%$ of the respondents who were illiterate were more satisfied compared to $(22.25 \%)$ who were in university. This finding is consistent with the studies conducted by Tayelgn, et al, in which less educated patients tended to have high satisfaction. ${ }^{12}$

Mothers' level of satisfaction was also related to the monthly family income as among mothers who assess the delivery as (good), the high percentage of them $(63 \%)$ belonged to the income group of less than 500 EGP while $(51.2 \%)$ belonged to the income group of more than 1000 EGP. And among those who assess the delivery as (very good), (25.6\%) belonged to the income group of less than 500 EGP while $(48.8 \%)$ belonged to the income group of more than 1000 EGP with a highly significant difference $(\mathrm{P}<0.000)$.

Table 6: Relation between assessments of delivery and educational status.

\begin{tabular}{|c|c|c|c|c|c|}
\hline \multirow[b]{2}{*}{ Item } & \multicolumn{4}{|l|}{ Educational state } & \multirow[b]{2}{*}{$\begin{array}{l}\text { p- } \\
\text { value }\end{array}$} \\
\hline & $\begin{array}{l}\text { Illiterate }(n=192) \\
48 \%\end{array}$ & $\begin{array}{l}\text { Read and Write } \\
(n=20) 5 \%\end{array}$ & $\begin{array}{l}\text { Primary and preparatory } \\
(n=99) 24.75 \%\end{array}$ & $\begin{array}{l}\text { University } \\
(n=89) 22.25 \%\end{array}$ & \\
\hline Excellent & $34(17.7)$ & 0 & 0 & 0 & \multirow{5}{*}{$\begin{array}{l}0.0001 \\
*\end{array}$} \\
\hline Very good & $60(31.2)$ & $0(0)$ & $44(44.4)$ & $25(28.0)$ & \\
\hline Good & $98(51.0)$ & $20(100)$ & $46(46.5)$ & $44(49.4)$ & \\
\hline Suitable & 0 & 0 & $9(9.1)$ & $10(11.3)$ & \\
\hline Poor & 0 & 0 & 0 & $10(11.3)$ & \\
\hline
\end{tabular}


Table 7: The relation between service expectation level and satisfaction of the mothers.

\begin{tabular}{|c|c|c|c|c|c|c|}
\hline Characteristics & $\begin{array}{l}\text { Number } \\
(\mathrm{N}=400)\end{array}$ & $\begin{array}{l}\text { Unsatisfied } \\
(\%)\end{array}$ & $\begin{array}{l}\text { Low satisfaction } \\
(\%)\end{array}$ & $\begin{array}{l}\text { Moderate } \\
\text { satisfaction (\%) }\end{array}$ & $\begin{array}{l}\text { High satisfaction } \\
(\%)\end{array}$ & p-value \\
\hline \multicolumn{7}{|c|}{ Service expectation level } \\
\hline Poor & 63 & $10(15.9)$ & $13(20.6)$ & $11(17.5)$ & $29(46)$ & \multirow{3}{*}{$0.03 *$} \\
\hline Fair & 88 & $11(12.5)$ & $23(26.3)$ & $13(14.6)$ & $41(46.6)$ & \\
\hline Good & 249 & $17(6.8)$ & $33(13.2)$ & $82(33)$ & $117(47)$ & \\
\hline
\end{tabular}

This agrees with Melese, et al study that demonstrated higher income clients had a higher level of satisfaction with health care providers' attitude and a lower level of satisfaction with the hospital environment. ${ }^{13}$

As regards explanation of the treatment plan for delivery to mothers, the majority of the studies investigated explanation of the patients' problem to the patient, explanation about examination or procedure to be done, and information to the patient on drugs prescribed to the patient and information and counseling to the patient on discharge has yielded a general satisfaction rate with decreasing order if not concerned.

The findings of our study would alert the health care system to design a client friendly approach to enhance communication

Regarding prenatal counseling, it is a major determinant of satisfaction, as it is critical for a woman's understanding of her health condition and her participation in the pregnancy and delivery process. ${ }^{14}$ The use of praising words by the medical staff or by the obstetrician or midwife during delivery encouraged women and boosted their self-esteem, as reported in a study conducted in Lebanon. ${ }^{15}$

In the present study $(42.75 \%)$ of the respondents have a problem in privacy and $(55.0 \%)$ of the respondents have a problem with blood donation and high percentage of respondents $(55.0 \%)$ suggests rendering the blood donation not be obligatory. So, this study revealed that the overall satisfaction of mothers on delivery service was found to be suboptimal.

Environment was found to be one of the major factors affecting client satisfaction outcomes. Of these dimensions, cleanliness is another important structural determinant of maternal satisfaction. This agrees with Dzomeku, et al. ${ }^{16}$ Therefore, this study helps to evaluate health care services from the patient's point of view, facilitate the identification of problem areas, and help generate ideas towards resolving these problems.

The overall proportion of mothers who were satisfied with delivery care was suboptimal. The study strongly suggested that more could be done to assure that the service provided is more patient centered.

\section{CONCLUSION}

Although most participants were satisfied by the delivery service provided to them during delivery, Dissatisfaction by a minority group resulted in a limited ability of communication with mothers, lack of privacy sensation during hospital stay and obligatory blood donation. Thus, mechanisms should be developed to increase maternal satisfaction in our hospital.

\section{Funding: No funding sources}

Conflict of interest: None declared

Ethical approval: The study was approved by the Institutional Ethics Committee

\section{REFERENCES}

1. Asadi-Lari M, Tamburini M, Gray D. Patients' needs, satisfaction, and health related quality of life: towards a comprehensive model. Health Qual Life Outcomes. 2004; 2:32.

2. Sagid MS, Baig MK, Quality of health care: an absolute necessity for public satisfaction, Int J Health Care Qualit Assuran. 2007;20(6):545-8.

3. Press Ganey Associate Inc, author, The Satisfaction Monitor, 1999, Mar-April, Empowered patients are more satisfied with their care. 1-2.

4. Hawkers N. Patient satisfaction levels remain in critical condition. Times News Papers Online, April 24, 2008.

5. World Health Organization (WHO), Making Pregnancy Safer: The Critical Role of the Skilled Attendant: A Joint Statement by WHO, ICM, FIGO, World Health Organization (WHO), Geneva, Switzerland, 2004.

6. Waldenstrom U, Borg IM, Ollson B, Skold M, Wall S. The childbirth experience: a study of 295 new mothers. Birth. 1996;23:144-53.

7. Anna J, Kone P. Organizational performance impacting patient satisfaction in Ontario hospitals: a multilevel analysis. Br Med C Res Notes. 2013;6(1): 509.

8. Buciuniene I, Blazeviciene A, Bliudziute E. Health care reform and job satisfaction of primary health care physicians in Lithuania. BMC Fam Pract. 2005;6(1):10.

9. Morris JB, Jahangir AA, Sethi KM. Patient satisfaction: An emerging health policy issue. Am Acad Orthop Surg. 2013;7(6):7-9. 
10. Atkinson S, Haran D. Individual and district scale determinants of users' satisfaction with primary health care in developing countries. Soc Sci Med. 2005;60:501-13.

11. Donabedian A, An Introduction to Quality Assurance in Health Care, Oxford University Press, New York, NY, USA, 2002.

12. 12. Tayelgn A, Zegeye D, Kebede Y. Mothers' satisfaction with referral hospital delivery service in Amhara Region, Ethiopia. BMC Preg Childbirth. 2011;11(1):78.

13. Melese T, Gebrehiwot Y, Bisetegne D, Habte D. Assessment of client satisfaction in labor and delivery session at a maternity referral hospital in Ethiopia. Pan Africa Med J. 2014;17:76.

14. Ghobashi M, Khandekar R. Satisfaction among expectant mothers with antenatal care services in the musandam region of Oman. Sultan Qaboos Univ Med J. 2008;8:325-32.

15. Kabakian-Khasholian T, Campbell O, ShediacRizkallah M, Ghorayeb F. Women's experiences of maternity care: satisfaction or passivity? Soc Sci Med. 2000;51:103-13.

16. Dzomeku MV. Maternal satisfaction with care during labour: A case study of the Mampong-Ashanti district hospital maternity unit in Ghana. Int J Nurs Midwifery. 2011;3:30-4.

Cite this article as: Sayed W, ElAal DEM, Mohammed HS, Abbas AM, Zahran KM. Maternal satisfaction with delivery services at tertiary University hospital in Upper Egypt, is it actually satisfying?. Int J Reprod Contracept Obstet Gynecol 2018;7:2547-52. 